第29回日本老年医学会総会記録

<会長講演〉

\title{
老化機構と早老症
}

\section{熊原 雄一}

\begin{abstract}
〈要 約〉 老化は複雑なプロセスを経て起こると考学られるが，老化のメカニズムはこれまでプログ ラム説とェラー破綻説とを中心に, 突然変異説, 遊離基説, 架橋結合説など多くの説が出ているが, い ずれむ実証されていない，部分的早老はいくつかの疾患でみられる現象であるが，Hutchinson·Gilford プロジェリア症候群, Werner 症候群, Cockayne 症候群など代表的な遺伝的早老症について概説し, 自 然突然変異の起こし易さ，および遺伝子の修復能力について基礎的検討を行った。

6 チオグアニン耐性を指標とした突然変異の検討では, 正常人では末梢血リンパ球に拈いて加齢と共 に自然突然変異率が増加するが, Werner 症候群では末梢血リンパ球のみならず, 株化線維芽細胞におい ても正常対照に比して約10倍以上に増加していた。さらに突然変異の様式について，サザンブロット解 析により検討したところ, Werner 症候群では正常対照に比して広範囲欠失をおこしやすいことが明ら かとなった。したがってWerner 症候群ではDNA 複製の異常が早期老化と密接な関係を有するものと 思われた. Cockayne 症候群は紫外線高感受性を特徵として, DNA 修復に異常がある. Cockayne 症候 群由来株化線維芽細胞に, リボヌクレオチド還元酵素遺伝子の cDNA を導入したところ, 紫外線感受性 が部分的に回復した。リボヌクレオチド還元酵素はDNA 修復ではなく, DNA 前駆体であるデオキシリ ボヌクレオリド合成の律速酵素であることから, Cockayne 症候群はDNA 複製合成再開の調節遺伝子 に異常があると推測された。さらに早老症の原因と, DNA 修復複製過程との関係を示し, 老化機構に対 する早老症の位置づけを試みた。
\end{abstract}

Key words：老化, プロジェリア, ウェルナー症候群, コケイン症候群, DNA 複製

\section{緒言}

我が国における平均寿命は，すでに男性は75.2歳, 女性は80.9歳に達し, 昭和59年以来, 長寿国世界一の 座を守っている. 本邦における老年人口比率すなわち 65歳以上人口が全人口に占める比率は, 昭和 61 年の時 点で, $10.3 \%$ に達し, 今から 35 年先の 2021 年には $23.6 \%$ とピークを迎えると予測されている。このように高龄 化社会は今後さらに進行し, 老年病医学の対象となる 人口は，ますます増加していくものと予想される。老 化機構およびそのモデルとしての早老症の研究は, 極 めて重要なものである. 以下, 最近の当教室の研究結 果を踏まえ, 老化機構と早老症に関する基礎的臨床的 研究の一端を紹介する。

\section{1. 老化の特徵と老化機構}

1977年，G.M. Martin は，老化の基準として21項目

Y. Kumahara：大阪大学老年病医学講座
を選んでいるが1), 老化の特徴をよく現わしている。外 見的には, 白髪, 秃頭を認め, 臨床的に糖尿病, 性殖 器機能低下, 骨粗鬆症, 白内障, 脂質代謝異常, 自己 免疫など, 内分泌・代謝・免度系に，そして高血圧， 血管病変など循環器系に老化徵候が現われる.さらに, 悪性腫瘍の発症率の増加などが挙げられる、細胞遺伝 学的には, 幹細胞增殖能の低下, 自然突然変異・染色 体異常の高頻度出現などが知られている。病理学的に は, アミロイド,リポフスチンの沈着などを挙げるこ とができる。これらの特徵は内在的原因により現われ， 不可逆的でしかも有害である点で共通している。この よらな老化現象がなぜ起こるか，すなわち老化の原因 については古来多くの老化学説が提唱されてきた。

プログラム説は, 発生や成熟と同じく, 老化はあら かじめ遺伝子あるいは遺伝子群にプログラムされた現 象であるとする説であり, 動物種の最高寿命や，培養 細胞の寿命がほぼ一定であることに基づいている。こ れに対して, エラー破綻説とは, 細胞の情報伝達系に おける誤り，エラーが次第に蓄積して老化がもたらさ 
れるとする説であり，老いたラットでは，グルコース 6 リン酸脱水素酵素の易熱性分画が増加することが根 拠として挙げられている。

体細胞突然変異説は, 遺伝子の突然変異を老化の原 因とするもので，細胞の「情報そのもの」のエラーに よるといら説であり, 自己免疫疾患が加齢とともに増 加することに対しては，有力な学説である，遊離基説 は，活性酸素すなわちフリーラジカルが，生体成分と 反応して過酸化物を形成し，エラーを生じたり，変異 蛋白が蓄積して老化がおこるという説であり, リポフ スチンの形成が根拠となっている。架橋結合説は,

DNAのような高分子が，架橋物質により他の高分子 と結合し，凝集体として蓄積するといら説であり，ブ ドウ糖による架橋形成が最近注目を浴びている。

これらの学説は細胞レベルで適用可能なものである が，基本的にはプログラム説とエラー説に分類可能で ある. その他，更に高等生物に考兄られる説として， 免疫異常説, ストレス説, 内分泌説, 神経伝達物質説 などが提唱されている。老化機構に対して，このよら に数多くの仮説が考兄られているが，いずれも実証が 困難である。

\section{2. 早老症}

さて，老化機構の臨床的モデルとして早期老化症候 群, 略して早老症がある。早老症は, 性腺機能低下, 動脈硬化, 白内障, 骨粗鬆症などの老化現象が暦年齢 に比べて早期より進行する疾患群である.Martin 博士 はMcKusik 著の Mendelian Inheritence in Man に 記載された疾患のなかから老化形質をスコア化し，早 老症べストテンを選定した ${ }^{11}$. 臨床的には, 完全ではな く部分的に早老徵候を示すため, 部分的早老症とも呼 ばれ, 染色体異常に基づくものと遺伝的早老症とに大 別されるが, 遺伝的早老症は老化遺伝子の観点から注 目されている。

(1) Hutchinson-Gilford progeria

Hutchinson-Gilford progeria 症候群, 略してプロ ジェリアとよばれるが，この症候群は，幼児期より成 長が遅れ，小児期より老化徴候が出現し，多くは心筋 梗塞により10歳代で死亡する。

外見的特徵としては, 低身長, 秃頭, 水頭症様顔貌 を示し，皮膚は強皮症様に萎縮する。歯牙，頭蓋骨， 四肢骨に発育不全, 形成異常が認められ, 動脈硬化症 や，血栓症などの循環器系合併症が必発する。孤発例 が多く遺伝形式が明らかでない，当科で経験したプロ
ジェリアの 1 症例を紹介する ${ }^{2)}$.

44歳, 男性, (主訴) 労作時狭心痛

（現病歴）幼児期より水頭症様顔貌を示し，12歳頃 より低身長, 20 歳には全秃頭になる。39歳, 収縮期高 血圧を指摘され, 44歳労作時狭心痛, 呼吸困難にて当 科に入院した。

（家族歴）近親婚なく，両親，同胞とも特に異常を 認めない。

（現症）身長 $132 \mathrm{~cm}$, 体重 $24.5 \mathrm{~kg}$. 体格：小, 外反 股, 騎乗様肢位を認む。血圧：236/80 mmHg. 脈拍： 87/分, 整. 知能・精神状態: 正常. 皮膚: 老人様萎縮, 色素沈着, 上肢, 手背, 頝部の静脈怒張著明, 毛髪: 全秃頭, 腋毛・恥毛なし。

（頭部）頭蓋は下顎に比し大きく, 水頭症様。下顎 骨の形成不全, 多数の歯牙欠損を認む。 耳架なし。眉 毛・睫毛は粗. 眼球：軽度突出. 眼底：異常なし, 甲 状腺・リンパ節：異常なし。

（胸腹部）心濁音界：やや拡大. 心音：大動脈弁領 域より肺動脈弁領域にかけて収縮期および拡張期雑音 (Levine III/VI). 肺呼吸音：異常なし。腹部：異常な ᄂ.

（下肢）浮腫認めず。両膝関節硬直, 両足尖端部壊 疽. 両足背動脈：触知不能. 腱反射：正常.

(X 線検査) 動脈石灰化著明.

（心電図）完全右脚ブロック，左室肥大，心筋障害. この患者は，45歳にて，心筋梗塞で死亡した。プロ ジェリアとしては，世界で最も長命であった。剖検で は心蔵は両室肥大を示し, 多数の心筋梗塞像を認めた. 冠状動脈には高度の動脈硬化と血栓を認め, 大動脈弁, 肺動脈弁の高度石灰化が確認された。脳皮質は萎縮な く, 梗塞も出血像も認められなかった。腎臓は細動脈 性腎硬化症を示し, 䁄丸は正常であるが, 精子は低形 成であった。

(2) Werner 症候群

ウェルナー症候群は，1904年「強皮症を併発した白 内障」として報告された早老症3)であり，常染色体性劣 性遺伝で, 同胞内発生を認めることが多い。低身長, 白内障, 皮膚の萎縮硬化, 白髪, 脱毛を特徵とし, 間 葉系悪性腫瘍が好発する。以下にウェルナ一症候群の 1 例を紹介する.

36歳, 女性 (主訴) 高血压, 糖尿病の精査

(現病歴) 22 歳頃視力低下に気づき, 近医にて若年 性白内障を指摘された。33歳, 白髪が急に増加し，34 歳には両足趾の变形拘縮のため足趾形成術を受け，36 
歳時, 高血圧, 糖尿病精查のため当科入院. 父：糖尿 病, 母：高血圧・脳血管障害 (43歳にて死亡). 同胞 3 名.

（家族歴）患者の妹に高血圧, 白内障, 白髪と, 患 者と同じ症状を認め, ウェルナー症候群と考えられた.

(現症)身長 $145 \mathrm{~cm}$, 体重 $35 \mathrm{~kg}$. 血圧 $160 / 100 \mathrm{mmHg}$, 脈拍 $96 /$ 分, 整.

（皮膚）全身皮膚に硬化性変化。足底角化著明.

(頭部) 頭髪やや疎, 白髪. 鳥様顔貌。高張な声。 眼底異常なし。

（胸腹部）三尖弁領域に心収縮期雑音（Levine III/ VI). 肺呼吸音正常. 腹部異常なし。

（神経学的所見）両側肢腱反射元進，病的反射なし.

\section{3. 早老症における内分泌異常}

これら早老症症例において内分泌学的異常を検討し た.ブドウ糖負荷試験の結果では, 両例とも, 空腹時 血糖値は正常であったが, 1 時間值は $200 \mathrm{mg} / \mathrm{d} l$ を超 えており，糖尿病パターンを示していた。更にウェル ナ一症候群では，著しい血糖值低下の遅延が認められ た、インスリン值は，空腹時は正常範囲内であるが， ピーク值は両者とも $200 \mu \mathrm{U} / \mathrm{m} l$ を越えており, インス

リン抵抗性のパターンであった。

インスリン負荷テストでは，30分後での血糖值は前 値の $50 \%$ 以下に低下しておらず，やはりインスリン抵 抗性を示していた。成長ホルモンは, 前值は正常範囲 内にあるが，ピーク値は $10 \mathrm{pg} / \mathrm{m} l$ を越えて抢らず，特 にプロジェリアでは無反応であった。これは，インス リン抵抗性のため血糖降下が不十分なため, 成長ホル モンの分泌刺激とならなかったためと思われた。ウェ ルナー症候群は赤血球あるいは線維芽細胞において, インスリンレセプターに異常がないことが示されてお り,インスリン抵抗性は, ポストレセプターの異常に よるものとされている4).

副腎性アンドロジェンである DHEA-Sulfate の血 中レベルは加齢とともに直線的に減少することが知ら れており，加齢現象の一つの指標と考号られている. 我々のプロジェリアの例はおよそ80歳位の值を示して いた。

\section{4. 早老症における免疫能}

早老症における免疫能, 特に $\mathrm{T}$ リンパ球の機能につ いて検討した、 Tリンパ球の mitogenであるフィトへ マグルチニン, コンカナバリン A によるリンパ球幼若
化試験では，正常コントロールに比して，プロジェリ アでは約 $40 \%$ に, ウェルナー症候群では約 $30 \%$ に低下 していた。このように両者ともに，Tリンパ球の分裂 能が低下していることがわかった。

OKT4サブセットはヘルパーT細胞とインデュー サーT 細胞を, OKT8サブセットはサプレッサーT 細 胞とキラーT 細胞を示すものとされている.この両者 の比は，免疫調節機構のバランスを示し，たとえば， SLE や慢性関節リウマチなどの自己免疫疾患では, こ の比は高値を取り, B 型肝炎やエイズなどのウイルス 感染症では低值を取ることが知られている.

この OKT4/OKT8比は, プロジェリアでは3.1, ウェ ルナー症候群は5.3で, 正常1.54〜1.98に比し上昇して いた。これは，自己抗体を作りやすい状態を示してお り, 免疫調節機構のアンバランスが存在することが示 唆された。

\section{5. 早老症における細胞レベルの老化機構}

次に, 早老症の細胞レベルにおける老化の特徵を検 討した. 正常者では年齢と細胞寿命とは反比例するこ とが知られ, 又, ウェルナー症候群, プロジェリアは ともに細胞寿命はいちじるしく短縮しているとされて いる5).

末梢血リンパ球を用いて， 6 チオグアニン耐性を マーカーとして自然突然変異率が調べられているが, 加齢により, 突然変異率は増加し, 両者は相関関係を 示すことが明らかになっている。そこで, ウェルナー 症候群の細胞では自然突然変異率が増加しているか否 かを末梢血リンパ球及び株化線維芽細胞で検討した.

まず，自然突然変異率は 6 チオグアニンの耐性獲得 を指標とした，正常細胞は，6チオグアニンといら薬 物の存在下では死隇する。ヒポキサンチングアニン フォスフォリボシルトランスフェラーゼ (HGPRT) は, グアニンから直接グアニン 1 リン酸を合成する酵 素である.HGPRTが久損している細胞は 6 チオグア ニンに耐性となり，しかも HGPRT の遺伝子に何らか の欠陷があることが知られている．6チオグアニンに 感受性の細胞と耐性の細胞との比率がわかれば, HGPRT 遺伝子の欠損する比率がわかることになり, 突然変異率を知ることが可能である.

末梢血リンパ球に拈ける自然突然変異率を検討した ところ, ウェルナー症候群では正常対照に比して約 10 倍の自然突然変異率の増加が見られた．株化線維芽細 胞に打ける自然突然変異率でもやはり同様に, ウェル 
表 1 ウェルナー症候群における老化促進因子

1）自然突然変異率の上昇……DNA 複製異常

(DNA 修復能は正常)

2）免疫能の低下 リンパ球分裂能低下 胸腺萎縮

3）耐糖能異常 ポストレセプター異常

4）動脈硬化の進展 (脂質代謝は正常, 耐糖能異 常, 突然変異などが関与か?)

ナー症候群で，10倍以上に増加していた ${ }^{6)}$.

そこで，6チオグアニンに耐性となった変異細胞に おける，HGPRT 遺伝子の変異様式を検討した。突然 変異には， 1 個の塩基の置換による点突然変異, DNA の欠落による欠失变異そして余分な DNA が挿入する ことによる插入変異とがある。サザンブロッティング 解析法を用いると, 約 100 塩基以上の大きな变化であれ ば検出することが可能である。

HGPRT の cDNA をプローベとして，種々の制限 酵素を用いて，サザンブロッティング解析を行ったと ころ，変異細胞において欠失変異が多数認められた。 さらにDNA 欠失の頻度を検討したところ，正常者由 来の細胞から分離した変異細胞では，広範囲欠失を生 じる頻度は $29 \%$ であったが，ウェルナ一症候群由来の 細胞から分離した变異細胞では，63\%あるいは $86 \%$ と きわめて高值であった。すなわち，ウェルナー症候群 はDNA の複製異常が高率に抗こり，しかも比較的大 きな欠失を打こしやすいことが明らかになった。ウェ ルナー症候群では, 悪性腫瘍の合併が高率に見られる が，いわゆるガン抑制遺伝子の欠失により悪性腫瘍が 発生することがこのデータから推測される.

以上にのべたウェルナ一症候群に打ける老化促進因 子とその原因についてまとめると(表 1 )，まず，自然 突然変異の増加は, DNA 複製の異常によるものと考 えられる。免疫能の低下は, 胸腺の萎縮や Tリンパ球 の分裂能の低下により示される。耐糖能異常は, イン スリン感受性の低下によるが，インスリンレセプター レベルでは正常であるとされ，ポストレセプターレべ ルの異常とされている.動脈硬化傾向については, 1986 年, Penn らの一派が, 粥状硬化巣に, 形質転換活性の ある遺伝子が存在することを示し7)，突然変異と動脈 硬化との関係が示唆されている。

\section{6. コケイン症候群と DNA 修復}

最後にコケイン症候群について，最近の知見を紹介 する.
コケイン症候群は, 脂肪組織の減少，低身長を示し， 多くは進行性の知能障害を認める。老人様顔貌で，色 素性網膜变性，視神経萎縮などの眼症状，感音性難聴 や運動失調などの神経症状，光線過敏症を示す。病理 学的には脳血管系の石灰沈着が認めら机る。

コケイン症候群の皮膚線維芽細胞は紫外線に高感受 性であることが特徵的とされている，紫外線照射後の DNA 合成の経時的变化を調べてみると，正常では紫 外線照射後, DNA 合成は一旦低下した後, 次第に増加 するが、コケイン細胞では，DNA 合成は低下したまま で，やがて細胞は死滅していくことが示されている. 紫外線は，主にチミジンの 2 量体を形成させて，DNA に損傷を与えるが, 損傷を受けた細胞はまず DNA 複 製が停止し，その後にDNA 修復が行なわれ, 複製が再 開する。コケイン症候群では DNA 修復過程，特に DNA 修復後の複製再開に異常があるとされてい $ろ^{8)}$.

コケイン細胞の薬剤感受性を調べたところ，IDNA ポリメラーゼ $\alpha$ の阻害剤であるアフィディコリンに 感受性であることが示された。アフィディコリン 0.09 $\mu \mathrm{g} / \mathrm{m} l$ では，正常は $50 \%$ 程度の増殖に阻害を受ける が，コケイン細胞では $99.5 \%$ 阻害された。また，紫外 線耐性となったコケイン細胞復帰变異株では，アフィ ディコリンに対しても正常耐性に復帰していた。した がって, 紫外線感受性とアフィディコリン感受性とは, 密接な関係を有することがわかった。

次に，コケイン細胞に，マウス由来のリボヌクレオ チド還元酵素の遺伝子を導入した場合，紫外線感受性 が回復するかどうか調べてみたところ，リボヌクレオ チド還元醭素の遺伝子を導入すると紫外線感受性が部 分的に回復することがわかった。リボヌクレオチド還 元酵素は DNA 修復酵素ではなく，DNA 前駆体とな るデオキシリボヌクレオチドの合成の律速酵素であ

図 1 DNA 修復複製過程と遺伝的早老症（仮説）
DNA 損傷
$\downarrow$
DNA 複製合成阻止……......梢血管抎張性小脳失調症
DNA 修複………...............素性乾皮症 $\underset{\downarrow}{d N P}$ 合成

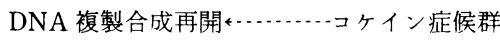 $\downarrow$
DNA 複製………………ウェルナー症候群 
る、したがって、リボヌクレオチド睘元酵素遺伝子の 導入は，DNA 前駆体の増加をもたらし，DNA 複製再 開筫いたと考えられる。宥た、コケイン症候群は DNA 修復酵素の構造遺伝子には異常がなく，その調 節遗伝子の異常である々推測される。

以上の知見をもとに, DNA 修復複製過程と早老症 Łの関係について，考察を行った（図 1).

DNA 修復複製過程は, DNA 複製阻止, DNA 修復, DNA 複製再開. DNA 複製の 4 つの段階に分けること ができる、そして，DNA 複製阻止の異常は，X 線感受 性の末梢血管拡張性小脳失調症で多られる 復の異常は色素性乾皮症に，DNA 複製再開の異常は コケイン症候群に, DNA 複製の異常はウェルナ一症 候群にそれぞれ対応すると考えられる。

そして,色素性乾皮症は早老症を示さないことから， 早老症は特に DNA 複製の調節に密接な関連を有する ことが推測される，又，正常老化では，老化機構の中 にDNA 複製調節の変化といら段階が存在し, 早老症 では，この段階の遺伝的異常のため，早期老化をきた すと考えられる。

\section{7. 結語}

1. 正常老化と早老症について概説した。

2. 正常老化にみられる内分泌・免疫・代謝機能の変 化は, 早老症の場合にはより顕著であり, 老化機構の 臨床的モデルとなる.

3. 正常老化では自然突然変異の頻度が増加するが, ウェルナー症候群では，正常に比して更に自然突然変 異の頻度が増加しており, その様式として, DNA の広 範囲欠失が高率に認められた。したがってDNAの複 製機構の異常は老化を特に促進する因子であることが 推測された。

4.コケイン症候群の紫外線高感受性はリボヌクレ オチド還元酵素遺伝子の導入により回復し，DNA 修 復後の複製合成再開レベルの調節に異常のあることが 明らかとなり，DNA 複製調節遺伝子の異常が早老と 関係するものと推測された。
謝辞：本研究は田中亀代次, 岡田善雄 (以上大阪大学細胞 工学センタ一), 山村研一(熊本大学医学部遺伝研究施設), 福地研一郎, 紙野晃人, 荻原俊男, 三木哲郎, 名倉 潤, 真 杉文紀 (以上. 大阪大学医学部老年病医学講座), 波多 丈(東 大阪市立東病院）の各先生の協力のもとに行われたもので あり，ここに各氏に心から謝意を表します。

\section{文献}

1) Martin GM : Genetic syndromes in man with potential relevance to the pathobiology of aging, In: Genetic Effects on Aging, Birth Defects : Org. Artic. Ser. (D. Bergsma and D.E. Harrison, eds). The National FoundationMarch of Dimes, New York, 1977.

2) Ogihara T, Hata T, Tanaka K, Fukuchi K, Tabuchi Y, Kumahara Y: Hutchinson-Gilford progeria syndrome in a 45 -Year-Old man. Am J Med 81: 135-138, 1986.

3) Werner O : Über Katarakt in Verbindung mit Sklerodermie. (Doctoral dissertation, Kiel. Univ.) Schmidt \& Klauning, Kirl, 1904.

4）坂本美一, 茂久田修, 伊藤康男, 石橋明人, 松田文 子, 葛谷 健：耐糖能異常とインスリン抵抗性の 成因. Diabetes Journal 13：15一20，1985.

5) Martin GM, Sprague CA, Epstein CJ: Replicative life-span of cultivated human cells: Effects of donor's age, tissue and genotype. Lab Invest $23: 86-92,1970$.

6) Fukuchi K, Nakura J, Kumahara Y, Uchida T, Ohada Y: Elevated spontaneous mutation rate in SV40-Transformed Werner syndrome fibroblast cell lines. Somat Cell Mol Genet 11 : 303-308, 1985.

7) Nesta D, Minidich B: Transforming gene in human atherosclerotic plague DNA. Proc Natl Acad Sci USA 83 : 7951-7955, 1986.

8) Tanaka K, Kawai K, Kumahara Y, Ikenaga M, Okada Y: Genetic complimentation groups in cockayne syndrome. Somatic Cell Genet 7 : 445-455, 1981.

9) Painter RB, Young BR: Radiosensitivity in ataxia telangiectasia: A new explanation. Proc Natl Acad Sci USA 77 : 7315-7317, 1980. 


\section{Abstract \\ Mechanism in Normal Aging and Progeroid Syndromes}

\section{Yuichi Kumahara}

It is widely known that the aging is processed by complex mechanisms. These mechanisms include two main theories, program theory and error catastrophy theory. Other theories are mutation theory, free radical theory, cross-linkage theory, autoimmune theory and so on. However, at present, there is no established theory to account for the all phenomenon accompanying in aging. In this paper, the complex mechanism in aging is outlined, and some progeroid syndromes as a model of normal aging are also introduced including the results of our recent studies. In normal aging, the life span of fibroblast reduces and the incidence of spontaneous mutation rate increases in in vitro study. In Werner syndrome, the incidence of spontaneous mutation rate of lymphocyte or fibroblast was about ten times higher than that in normal elderly. This was mainly caused by

Department of Medicine and Geriatrics, Osaka University Medical School, Fukushima-ku, Osaka 553, Japan the large deletion of gene which was studied using Southern blot analysis. This may be associated with the mechanism of aging in Werner syndrome. SV-40 transformed fibroblasts from Cockayne syndrome was highly sensitive to UV irradiation. This high sensitivity was partially recovered by the introduction of cDNA of ribonucleotide reductase which is a rate limiting enzyme of deoxyribonucleotide synthesis. This may suggest that the regulatory deficit of the initiation of DNA replication may be related to the aging in Cockayne synerome. The mechanism of aging in progeria was more complex than that in Werner syndrome or Cockayne syndrome. We have a case of aged progeria of 45 years old who had a severe systemic arteriosclerosis with calcification and cardiovascular diseases. It is suggested that aging is caused by the multi-mechanisms including the abnormalities in the DNA replication.

key words: aging, progeria, Werner syndrome, Cockayne syndrome, DNA replication (Jpn J Geriat 25: 1-6, 1988) 